Int. Agrophys., 2021, 35, 375-388

INTERNATIONAL

\title{
Foamed bioplastics: a review
}

\author{
Maciej Combrzyński ${ }^{1}{ }^{10} *$ and Özge Özmen ${ }^{2}$ \\ ${ }^{1}$ Department of Thermal Technology and Food Process Engineering, University of Life Sciences in Lublin, \\ Głęboka 31, 20-612 Lublin, Poland \\ ${ }^{2}$ Department of Food Engineering, Mersin University, Çiftlikköy Kampüsü, 33343 Mersin, Turkey
}

Received October 7, 2021; accepted December 22, 2021

\begin{abstract}
Based on a literature review, the development and importance of foamed bioplastics in the context of conventional materials has been discussed in the paper. Raw materials, technological aspects, types of products (including a new generation of bioplastics), their advantages and disadvantages as well as user expectations are presented. Despite considerable progress, especially in the formulation of new raw material compositions, there is still a need to continue research work on the application of different techniques in the production of biodegradable porous packaging materials. It still remains the current primary goal - to produce products with physical characteristics that are comparable with those of petroleum based plastic.
\end{abstract}

Keyw ords: physical properties, foams, porous materials, bioplastics, starch-based packaging materials

\section{INTRODUCTION}

Foamed elastic materials are commonly used and have important functions in many areas of human life (Banhart and Baumeister, 1998; Borchardt, 2004; Gendron, 2004; Gibson and Ashby, 2001). They occur both in nature (as materials of natural origin) and as a result of different technological processes. This group of materials is characterized by a high degree of porosity combined with a high level of stiffness and very low bulk density. Because of this, cellular materials often act as building blocks (wood, bones). Spongy materials may be used to produce heat and power insulators, sound absorbers, shock absorbers and fluid beds among many other uses. They are based on a porous structure that provides stable, permanent characteristics. The pore spaces

*Corresponding author e-mail: maciej.combrzynski@up.lublin.pl may or may not contain gaseous or liquid media. It is a surprising fact that not all porous materials actually have pores. Holes and gaps may be the result of a defect which lowers the mechanical strength of the material. In this case it cannot be classified as a spongy material. A porous material is characterized by two factors: the first is the large number of pores, the second is their function, which is determined by their physical and chemical properties (Konovalenko et al., 2014; Sivertsen, 2007; Song et al., 2017). Wool and polystyrene are examples of porous materials which are poor heat conductors due to the presence of air inside the structure. This feature is an advantage when they are used in construction (building materials), these materials are also used in the textile and refrigeration industry.

The number of pores depends on the type of spongy material. There are low, medium and high porosity materials (Liu et al., 2014; Todd and Kuznetsova, 2011). It is assumed that the first two types have a closed pore structure resembling dense crisscrossed connections. Among the plastics with a high degree of porosity, depending on the differential pore morphology and the continuity of the solid structure, three distinct cases should be distinguished. The first solid structure consists of a two-dimensional pattern in which the three-, four- or hexagonal pore sections are separated from one another in a space in the form of polygonal columns. This type of structure resembles a hexagonal honeycomb

(C) 2021 Institute of Agrophysics, Polish Academy of Sciences 
cell. Similar materials have similar structures, but they are characterized by the presence of directional pores, i.e. elliptical or circular sections (Gendron, 2004; Mitrus and Mościcki, 2014). This kind of structure significantly reduces the possibility of the mutual penetration of porous cells and is characterized by a lower density of the pore pattern in cross section. The second type of high porosity material is characterized by a meshed, three dimensional structure with interconnected open pores. In the third case the structure of the material has the shape of a sphere, an elliptical sphere or a polyhedron. In all three cases the high porosity materials can be constructed from open or closed pores. One particularly exemplary and porous material is a hierarchically structured product (Geramipour and Oveisi, 2017; Su, 2012; Wu et al., 2021). They are defined as materials containing a structure of connected pores of different lengths. Among them, various pores $(<2 \mathrm{~nm}-$ micro, $2-50 \mathrm{~nm}-$ meso, $>50 \mathrm{~nm}-$ macro) can be distinguished. The porous solid, due to the origin of the porous structure, can be categorized into the artificial and the natural (Gibson and Ashby, 2001; Liu et al., 2014; Rajak et al., 2020). Artificial porous materials can be made from metal, ceramic and plastics. Natural porous materials are rocks, soils, wood, fibrous materials and bones that are built up inside the bodies of the living.

The end of the twentieth century brought about significant changes in the development of packaging (Arif et al., 2007; Chen et al., 2002; Doi and Fukuda, 1994; Gáspár et al., 2005; Lehmhus et al., 2013). A growing demand for disposable packaging, as well as modern forms of sales and technology have driven the role of packaging materials. The protective properties of packaging (the greatest concern for the manufacturers of goods), marketing function and the economic factor - are important topics for traders and economists. The environmental pollution caused by discarded waste packaging is a significant subject matter not only for ecologists, but also for the relevant authorities and also for the general public - the consumer, who is keen to maintain a natural balance in the surrounding ecosystem. Contemporary packaging must meet specific requirements at each stage of its usefulness (Cucina et al., 2021; Engel et al., 2019; Warburton et al., 1990).

At present many kinds of plastic materials are available on the market, which are characterized by a variety of properties, easily satisfying the producers of different goods. The great advantage of polymers is that they can be mixed with each other, and even used in conjunction with other packaging materials, e.g. with paper or aluminium foil. The popularity of plastics is due to their ease of molding, performance, durability and low production costs. At present, plastic packaging is fully developed with extremely desirable mechanical properties, low density, excellent durability and it is also relatively inexpensive to produce (Jiang et al., 2020; Kaza et al., 2018; Sivertsen, 2007). Due to their properties, and especially their relatively low price, they successfully compete against other groups of packaging materials. The packaging industry has been one of the largest users of plastics for many years, nearly half of the volume produced is used to manufacture food packaging (Andersen et al., 1999; Chaireh et al., 2020; Engel et al., 2019; Salgado et al., 2008). This has created a great social, economic and global problem (Averous et al., 2000; Brodin et al., 2017; Cha et al., 2001; Cinelli et al., 2006; Zhang et al., 2020). New technologies for the production of recyclable and/or biodegradable packaging materials are required to solve this (Machado et al., 2020a; Park and Hettiarachchy, 1999; Szpiłyk et al., 2021; Yu et al., 2006). An attractive alternative may be biodegradable bioplastics, which are designed to decompose after being used and discarded. Polysaccharides, e.g. starch are among the most promising starting materials for the production of bioplastics, this has been confirmed by an expanding number of scientific articles that have been published in recent years (De Graaf and Janssen, 2000; Engel et al., 2021; Follain et al., 2006; Guan and Hanna, 2005; Shey et al., 2006).

The aim of this paper was to conduct an in-depth review of the subject of foamed bioplastics, year after year they play a more important role in the global material economy, mainly due to environmental reasons and a growing social awareness of packaging waste management.

\section{POROUS PLASTICS}

Plastics production involves a large number of polymers and additives. This allows for many modifications and also for the processing of various types of materials. The term "polymeric foamed materials" refers to a plastic material with a bubble structure but it also refers to materials with a mesh structure, or in more common vocabulary, foamed materials are simply called foams (Andrady, 2003; Liu et al., 2014; Mittal, 2013; Wang et al., 2020). They are described by the presence of various gas compounds in the pores, as in polymer composites and other materials in which the gas is placed deliberately. Foam polymers are used in the production of protective packaging, insulating sleeves and also in a variety of flexible thermoplastic products among other applications.

Polymerized foam is the result of research work mainly dating from the beginning of the last century. In the 1930s the first polymer foam was made (Rosato et al., 2004; Sivertsen, 2007). In 1931 the material used in for its production was polystyrene. Polyurethane was invented by dr. Otto Bayer. This material was used during World War II as a gum substitute and as a protective layer for wood and metal parts. After the war in the 1940s, polyurethane foam was first manufactured. The first group of foamed materials were used to protect goods during transport, particularly in the automotive and furniture industries. The potential for using such polymers over the next decade is obvious, the technology of producing foamed materials has progressed tremendously, giving rise to injection molding and other techniques, including extrusion. 
Polymerized foamed materials may be classified according to their structural properties, we can subdivide these materials into those with closed and open pores. They can also be classified according to pore density (high, medium and low density products) and their stiffness (rigid, semi-rigid and flexible materials). In the literature, these materials are also divided into thermoplastic and thermosetting materials among which we emphasize rigid and elastic products (Liu $e t$ al., 2014; Liu, 2010; Marcovich et al., 2017; Sivertsen, 2007).

Thermoplastics are generally intended for recycling as opposed to thermosetting materials, which are difficult to recycle due to their highly crosslinked structure. Polymers such as polystyrene (PS), polyurethane (PU), polyvinyl chloride (PVC), polyethylene (PE) and formaldehyde (UF) are used for the production of polymeric foams. Other commonly used constituents of foamed plastics include phenolics (PF), epoxy resins (ER), organosilicone resin (OS), cellulose acetate, polyethylene formaldehyde and polymethacrylate (PMMA). In addition, polycarbonate (PC), polypropylene (PP), polyamide (PA) and polytetrafluoroethylene (PTFE) have been used in recent years (Andrady, 2003; Lee and Scholz, 2009; Li et al., 2017; Razza et al., 2015).

Polyurethane can form rigid or flexible structures in foamed materials. It exists in many forms, it also has different characteristics depending on its use. Rigid polyurethane foamed materials are used as insulators and flotation plastics, to date, elastic equivalents have been used mainly in packaging (shock absorption and impact protection) (Gurusamy et al., 2020; Sivertsen, 2007). Polyurethane shingles are characterized by their relatively low density. In addition to polyurethane, the second most commonly used polymer for the production of expanded materials is polystyrene. Polystyrene is a very commonly used raw material in singlecomponent foamed materials due to its high strength, low thermal conductivity, low density and energy absorption value it is also a good thermal barrier, it provides very good sound insulation and it is competitively priced (Glenn and Orts, 2001; Kaisangsri et al., 2012). Like foamed metal and ceramic materials, polymeric materials can be combined with other materials to produce better composites and materials for specific applications, such as packaging.

\section{BIOPLASTICS}

According to the European Bioplastic Association, the family of bioplastics is currently divided into three main groups (Figs 1-3) (Atala and Mooney, 1997; Averous and Boquillon, 2004; European Bioplastics, 2021a; European Bioplastics, 2021b; Niaounakis, 2015):

- Materials that are bio-based or partially bio-based, as well as non-biodegradable plastics like bio-based polypropylene (PP), polyethylene (PE), or poly(ethylene terephthalate) (PET) which are known as "drop-in" solutions and technical/performance bio-based polymers such as PTT (polytrimethylene terephthalate) or TPC-ET (thermoplastic polyester elastomers).

- Materials that are both bio-based and biodegradable like polybutylene succinate (PBS), polylactic acid (PLA) and polyhydroxyalkanoates (PHA).

- Materials such as polybutylene adipate terephthalate (PBAT) that are biodegradable and based on fossil resources.

\section{Non-biodegradable but bio-based PET (“drop-in” solutions)} and polyolefines

Commercial plastics like PVC, PP and PE can also be created from renewable materials - most often from bioethanol (Bastioli and Rapra Technology Limited, 2005).

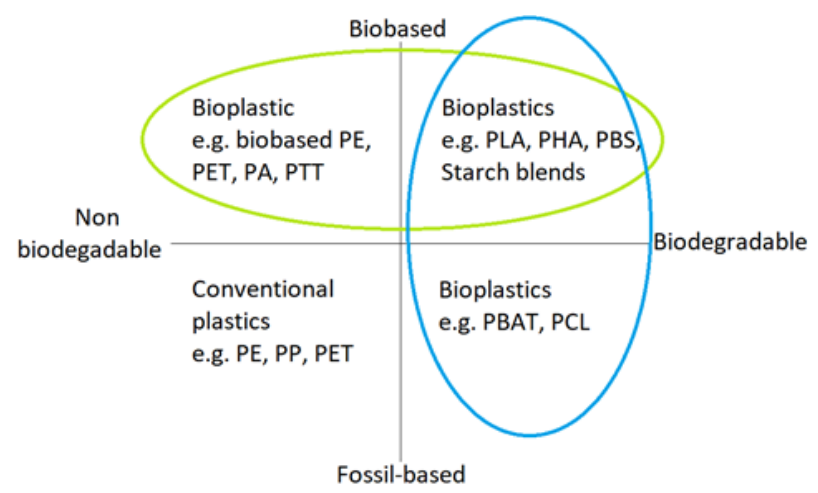

Fig. 1. Material coordinate system of bioplastics (based on European Bioplastics, 2021a).

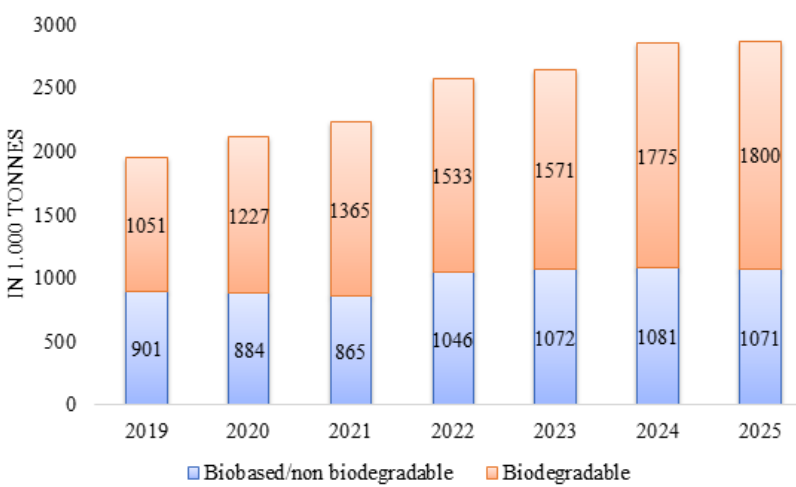

Fig. 2. Global capacity production of bioplastics from 2019 to 2025 (based on European Bioplastics, 2021b).

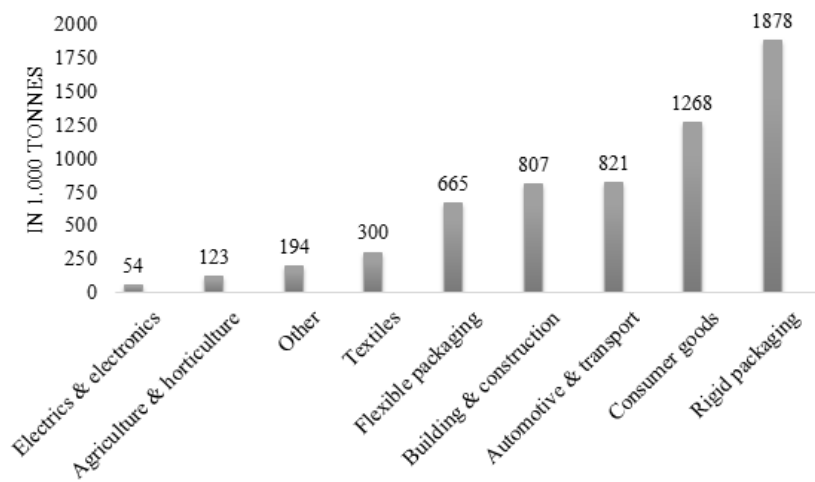

Fig. 3. Global production capacities of bioplastics in 2020 by market segment (based on European Bioplastics, 2021b). 
Bio-PE is already being produced, Bio-PP and Bio-PVC are in the final stage of being put into production. Polyester PET that is partially bio-based is used for technical applications and packaging, i.e. "Plant bottle" by Coca-Cola.

\section{Non-biodegradable but bio-based technical performance materials}

Within this large group of plastics we may find many specific polymers such as bio-based polyurethanes (PUR), polyesters (e.g. PTT, PBT), polyamides (PA) and polyepoxides that may be used as textile fibres (in the production of carpets and seat covers) and porous materials for casings, seating, cables and hoses (Bonin, 2010; Sivertsen, 2007).

\section{Biodegradable and fossil resource-based materials}

Plastics from this small group are most often combined with starch or other bioplastics, because of this, they have better functional and strength properties and may be termed "biodegradable" (Abe et al., 2022; Chocyk et al., 2015; Hutchinson et al., 1987; Mitrus, 2006; Oniszczuk et al., 2016). These biodegradable materials may still be obtained through petrochemical production processes. It should be emphasized that materials of this type which are partially bio-based have already been developed and it is very possible that they will be commonly available in the near future.

\section{Bio-based biodegradable plastics}

This group of plastics includes materials based on starch blends made from starch modified by thermoplastic processes as well as other biodegradable polymers and polyesters like polylactic acid (PLA) or polyhydroxyalkanoate (PHA) (Barmouz and Behravesh, 2017; Gamarano et al., 2020; Fang and Hanna, 2000; Guan et al., 2005; Li et al. 2021). Compared to cellulose materials (such as cellulose acetate or regenerate-cellulose), they have only been available on the market for the last few years. However they have primarily been used for short-lived products such as packaging, which is a large innovative area for the plastics industry to continue to experiment with, through the introduction of new kind of bio-based monomers such as propane diol, butanediol, succinic acid or fatty acid derivatives. A few products from this group, for the most part PLA, were created in a new way - which will make it possible to move away from some traditional forms of waste management, such as recycled materials. The possibility of using renewable raw materials is now the main subject of processing development.

The dynamic development of bio-based materials has allowed for improvements to be made in the potential of the plastics industry and also for new innovative and functional materials to be obtained (European Bioplastics, 2021b; Marcovich et al., 2017; Pachori et al., 2019; Wang et al., 2017). Products made from bio-based bioplastics may be identified by indicating their "bio-based carbon content" or their "bio-based mass content". A well-known procedure with which to check the bio-based carbon content in any kind of material is the EU standard with a code of CEN/
TS 16137 or the corresponding US-standard with a code of ASTM 6866, both of these have been established for years. It is unacceptable to state that a product is biodegradable without providing specific test evidence or specifications. If the material is described as biodegradable, more information about the level of biodegradability, the timeframe of this phenomenon and the required environmental conditions should also be noted. Organizations such as European Bioplastics recommend the provision of more specific information concerning compostability and for this information to be backed up with corresponding standard references (such as ISO 17088, EN $13432 / 14995$ or ASTM 6400 or 6868).

\section{FOAMED PACKAGING MATERIALS}

All sorts of packing fillers are routinely used in packaging. The choice of a suitable anti-shock protection depends on the type of packaging used, the shape and weight of the product, its susceptibility to mechanical damage, and the possible impediments which may be encountered during the transport and handling of the product (Lee et al., 2009; Mitrus et al., 2016; Tatarka and Cunningham, 1998; Wang-Nolan et al., 1995; Zhou et al., 2006). To date, plastic-based foamed packaging materials are the most popular choice, as they have many undisputed advantages such as a favourable degree of durability, water resistance and price (Bhatnagar and Hanna, 1996; Pushpadass et al., 2008; Wang et al., 2005; Zhang and Sun, 2007b).

One of the most popular polymers used in the production of foamed packaging materials is low density polyethylene (PE-LD) and polystyrene (Kaisangsri et al., 2014; Salgado et al., 2008). The PE-LD material produced has favourable damping properties, is lightweight and resistant to water, low gas and water vapour permeability. Foamed polyethylene is used to produce granules to fill the free spaces, thin protective plates, inserts and profiles of various shapes. The material which is commonly known as bubble film may also be included with these types of products. Produced from high pressure PE-LD, it usually consists of one or two flat layers of air bubbles that are placed evenly over the entire surface of the material. The required foil properties may be obtained by producing the appropriate density and bubble size. This type of material has very favourable cushioning and insulation properties. It is also used extensively also due to its ability to adapt to the shape of the protected product and tear resistance. Popular foamed polystyrene has found wide ranging applications in packaging not only due to its low density, favourable thermal insulation properties, durability and low production costs but also due to the ease with which packages of almost any form may be created (Hidalgo-Crespo et al., 2020; Ho et al., 2018; Soykeabkaew et al., 2004).

The dynamic growth of the processing and production of porous plastic is a result of the development of material engineering and the continuous improvement of their production technologies (Filli et al., 2011; National Institute of Industrial 
Research (India), 2006; Phromsopha and Baimark, 2021; Shogren et al., 2002). One example of this is conventional foamed polystyrene, which has been used for many decades in packaging and its volume of application is still growing continuously, despite widespread criticism (Soykeabkaew et al., 2004; Xu et al., 2005). The increase in the production of this material results in the pollution of the environment due to the use of raw materials of petrochemical origin, among which the most harmful are the foaming agents. Therefore it should come as no surprise that both consumers and legislators desperately want to implement new types of environmentally friendly packaging materials as soon as possible (Atiwesh et al., 2021; Kaisangsri et al., 2019; Tatarka and Cunningham, 1998; Willett and Shogren, 2002; Zhang and Sun, 2007a). Bioplastics would seem to provide an answer to these expectations. At the end of the 20th century, there was a perceivable increase in the amount of research into the development of biodegradable polymers from renewable, natural sources. Potential demand is enormous, however many issues of a technological and economic nature must still be solved.

\section{Foaming agents}

Many research centres have been working for years to develop and improve foam technology (Brodin et al., 2017; Chauvet et al., 2021; Jin et al., 2019; Kahvand and Fasihi, 2020). One important research aim is to strive to develop porous thin-walled structural elements and to obtain a gradient structure characterized by a varying degree of porosity along a certain cross-section. Research is also focused on increasing the area of polymer applications of foamed materials. The foaming agents are divided into: gases, liquids and solids. Gases and low-boiling liquids are introduced into the input material in the power supply section of the plasticizing system under pressure and using the appropriate equipment. The basic gas used is nitrogen, and less often $\mathrm{CO}_{2}$, carbon monoxide and hydrogen. Solid-state foaming agents and some liquids are added together with the raw material to the hopper or are delivered to the plastic at the time of its extrusion. At the moment of activation they form a gas. Prior to activation, the abrasive agents undergo the same processes as the material being processed (e.g. heating and compression). After activation, which occurs when the right temperature has been reached, a gas is released and its microcells dissolve in the extruded material. There are numerous microspheres that develop and, with high pressure, dissolve immediately in the processed material. The resulting pores can be filled with air or another gas (e.g. $\left.\mathrm{CO}_{2}\right)$, which is eventually replaced by air through the diffusion process.

The residue left after the foaming agent has finished reacting is colourless, non-flammable, mixed with polymer and odourless. The choice of a suitable foaming agent depends on the type of material being processed (Chauvet et al., 2021; Liu et al., 2014; Miladinov and Hanna, 2001; Sivertsen, 2007). The general rule is that the absorbent should have a decomposition temperature higher than the melting point and lower than the temperature at which the material is extruded. Therefore, it is important that the temperature of the head has a value close to the activation temperature of the distribution of the agent used. Another classification divides the foaming agents between the physical and chemical ones. Chemical foaming agents are chemical substances that react or break down by releasing chemicals in the foaming process. As a result of their decomposition the formation of pores in the structure of the material occurs. Among the chemical foaming agents are those with exothermic and endothermic decomposition characteristics. The exothermic decomposition characteristics include mainly hydracids and nitrogen compounds, e.g. nitrodicarbonamide, most commonly used during the foaming of polystyrene or PVC. The application of a foaming agent with exothermic decomposition characteristics often results in a superheated plastic with an irregular porous structure. The agents of this group are activated automatically, even after the supply of energy has ceased. Hence, a long and intensive cooling of the materials produced is required in order to obtain a suitable structure and prevent the deformation of freshly formed pores.

\section{ENVIRONMENTALLY FRIENDLY FOAMED PACKAGING MATERIALS}

In the case of foamed polymers, only decades after their invention, concerns were raised about their application since their production and use contribute to the depletion of the atmospheric ozone layer and has other negative effects on the environment (Andrady, 2003; Bruscato et al., 2019, Nabar et al., 2006b; Sivertsen, 2007). Such concerns were not only applied to foaming agents. The questions of waste disposal, their recycling and flammability have caused huge problems for the producers. An additional incentive to take new steps has been the introduction of new legislation and a number of restrictions on the use of certain substances (including chlorine, fluorine and carbon). Current work is focused on finding environmentally friendly foaming agents that can be used to replace those that have a negative impact.

Traditional, foamed polymeric materials are difficult to recycle for the most part. An example is polyurethane, which is a thermosetting compound, thereby making it a hard material to melt and reprocess. Research is also focused on the possibility of developing technologies for the production of biodegradable polymers that may be enzymatically degraded by bacteria and fungi and have properties similar to those of traditional synthetic materials (Ganjyal et al., 2007; Oniszczuk et al., 2015; Stevens, 2002). It is important that materials of this type can be processed with standard processing equipment and subjected to composting (organic recycling).

The manufacturers of foamed packaging materials are under increasing pressure from regulatory bodies concerning environmental regulations and waste disposal (Nabar and Narayan, 2006; Nabar et al., 2006a; Yang et al., 2013). They are a serious problem for businesses and municipalities 
because their products are difficult to manage, they do not decompose in the environment and recycling is often lossmaking due to expensive handling and transport. A lot of activity is currently focused on the possibility of reprocessing packaging materials, especially those with one-time use. This market is starting to require manufacturers to produce environmentally safe materials that must obviously also meet certain usability requirements. The growing interest in environmentally friendly materials has stimulated the development of the production of new packaging materials consisting of natural raw materials (Parra et al., 2006; Prapruddivongs and Wongpreedee, 2020; Steinbüchel, 2005).

At present, from the point of view of environmental protection the production of foamed polystyrene makes the most use of the raw material either from the initial stage and at the stage of the utility of postproduction wastes (HidalgoCrespo et al., 2020; Ho et al., 2018). The waste resulting from the cutting of foamed polystyrene is directly recycled to produce a material that can be reused. It can be recycled by using the pyrolysis and hydrogenation process, where it is possible to recover the raw material so that the waste becomes a full-fledged starting material. Foamed polystyrene waste can also positively influence soil properties by improving it. Ground foams can be used as a drainage and aerating material. In addition, it is useful in the process of composting organic waste from households. However, these examples illustrate the attempts of the producers to develop hard-to-handle foamed plastics, they are not able to reuse all of the manufactured waste materials. Hence, attempts have been made to use agricultural crops for the production of biopolymers (Glenn and Irving, 2005; Lawton et al., 2004; National Institute of Industrial Research (India), 2006). At present it is possible to make biodegradable packaging materials using starch, cellulose or protein. Biopolymers such as starch and cellulose have the advantage that the bioplastics based on them are suitable for composting.

However, the main task is to replace or significantly reduce the use of plastics in favour of biopolymer products. In 1989 the first starch-based foamed material was made as an alternative to plastics, it was obtained using the typical equipment of the traditional polymer industry (Cha et al., 2001). This type of product can be produced in a conventional extrusion process known for several decades in the processing of polymer porous materials, but also using the extrusion-cooking technique which is well known in the agro-food industry (Guy, 2001). Currently research is focused on the possibility of obtaining materials characterized by increased water resistance and similar functional characteristics as compared to their traditional counterparts (Bhatnagar and Hanna, 1995a; Bhatnagar and Hanna, 1995b; National Institute of Industrial Research (India), 2006). Starch is considered to be one of the main raw materials for making disposable foamed packaging (Abinader et al., 2015; Bergel et al., 2021; Chaudhary et al., 2009; Georges et al., 2018). Starch-based foamed packaging material is used in packaging, in the manufacture of sound insulators, sealants, displacement devices and various kinds of products useful in sports and leisure. These materials may have an even greater commercial potential if their manufacturing process is adapted to produce a variety of products with the desired properties, e.g. using natural substances that can improve the mechanical properties of the final product (e.g., fibre) (Cruz-Tirado et al., 2017; Guan et al., 2004; Guan and Hanna, 2004; Kaisangsri et al., 2012). Functional additives such as polylactic acid (PLA), polyvinyl alcohol (PVA) and hydrophobic substances like polycaprolactone (PCL), aliphatic aromatic copolyesters and cellulose acetate are also helpful. Next to $\mathrm{CO}_{2}$, polyvinyl alcohol (PVA) is one of the most popular blowing agents to be released as a gas during the processing of foamed bioplastics.

Starch foams are lightweight, so they can be successfully used as lose fillers during the transportation of many goods (Arif et al., 2007; Tatarka and Cunningham, 1998). Unfortunately, many of them are characterized by excessive fragility and/or poor water resistance. Unprotected, e.g. without the application of a protective coating they are completely soluble in water as opposed to synthetic foams that are neutral to moisture (Cha et al., 1999; Cha et al., 2001; Mitrus and Mościcki, 2014; Pushpadass et al., 2008). Andersen et al. (1999) reported that the addition of mineral fillers and wood fibres improves the strength properties of starch-based foams and, by using a coating wax, it is possible to improve the foam resistance to moisture. The disadvantage of this type of material is the limitations in creating optimum foamed cell structures required by potential consumers. The lack of industry-ready solutions is a challenge for the research centres to find an economically acceptable technology of the production of fully functional and biodegradable foamed materials.

As already mentioned, one of the methods of producing foamed packaging materials, is the application of an extrusion-cooking technique (Fig. 4), especially the use of food extruders known as "bioreactors". They are particularly well predisposed to this function due to their constructional adaptability to plant material processing. During extrusioncooking, the starch is liquefied and in the form of a gel and mixed with the foaming agent (Altskar et al., 2008; Bergel et al., 2020; Srisuwan and Baimark, 2021; Van Tuil et al., 2001). The most commonly used foaming agent is water and methanol in the form of steam. These agents allow for the air bubble material to be obtained in the starch structure. The structure and physical properties of the starch-based foams are dependent on a variety of factors, such as the type of starch, the ratio of amylose to amylopectin content, the additives used and the production process parameters (temperature, screw speed, hardware configuration, etc.). Open cells in the foam occur in the absence of one of the walls, resulting in an opening that connects adjacent cells. Following the strict recommendations of the technological regime (temperature up to $200^{\circ} \mathrm{C}$, the moisture of the mixture at over $15 \%$, the high rotational speed of the screw 
EXTRUSION-COOKING

mixing raw materials with additives

(fillers, foaming agents, plasticizers)

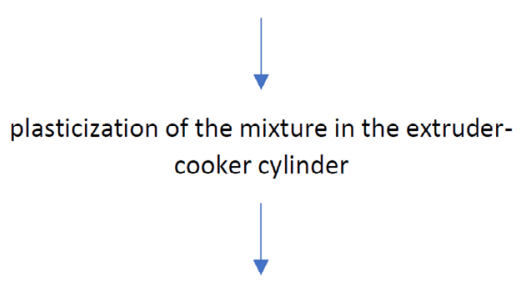

molding by the extruder-cooker die

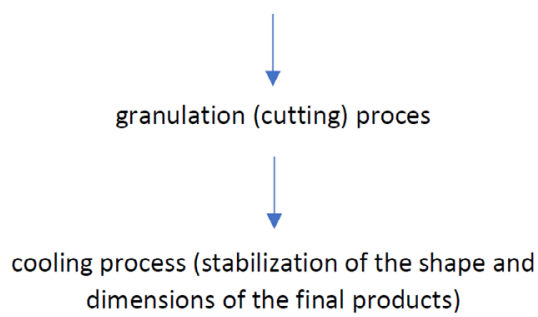

INJECTION MOLDING

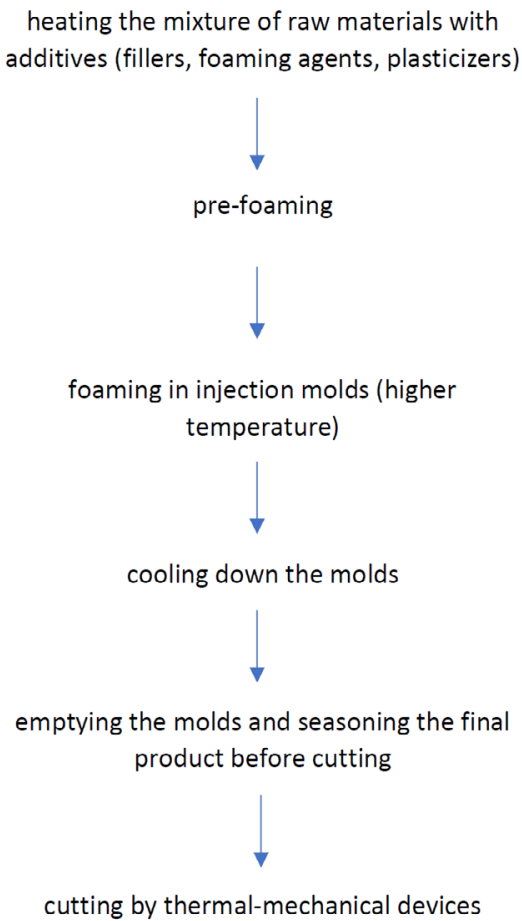

Fig. 4. Production of foamed bioplastics using the most popular techniques (based on Liu et al., 2014 and Mitrus and Mościcki, 2014).

- over $100 \mathrm{rpm}$ for a single-screw extruder, a die opening diameter of over $1 \mathrm{~mm}$ ), due to extrusion-cooking it is possible to obtain a continuous, direct foamed starch-based phase of good quality (Bergel et al., 2018; Chen et al, 2020).

Thermoplastic starch has a relatively weak durability because the water vaporization causes the cell walls to crack during the extrusion-cooking process (Mitrus and Mościcki, 2014). Starch foams (Fig. 5) are often characterized by an irregular structure of the open cells, which is the opposite of the ordered, mainly closed pores of the plastic material. It is difficult to obtain starch-like foamed material with a smooth structure and a large number of closed pores (Fig. 6). Nevertheless, it is a weak point of porous bioplastics when conventional "plastic-based" production methods and foamed agents are used. Materials which are commonly known as biocomposites (mixing, crafting of polymers with

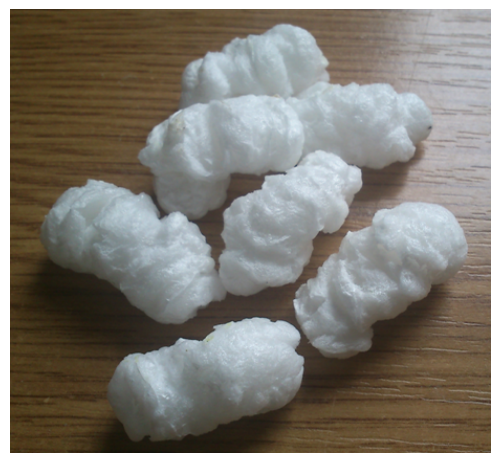

Fig. 5. Potato starch-like foamed material (based on own research). biopolymers) have become an attractive commercial alternative for producers. They have reached the point of having product properties very similar to those of their petrochemical counterparts. Unfortunately the negative effect of using biocomposite blends is their limited biodegradability.

Starch-based foamed materials may also be obtained by using the baking process (Salgado et al., 2008). Doughlike material (moisture content of $70-80 \%$ ) is foamed at the point of starch gelatinization, then it is dried. The process is carried out in a heated mould to obtain a thin shell porous structure. The middle layer is more porous than the thick top layer. This technology is somewhat limited by the low speed of moisture removal from the dough, which in turn limits the maximum wall thickness of the foamed structure. Mitrus and Mościcki (2014) also highlight the possibility of obtaining foamed material through the microwave heating


Fig. 6. Microstructure (porosity) of the two different starch-based foams: A - potato foam with polyvinyl alcohol (PVA) addition, $\mathrm{B}$ - potato foam with plastronfoam (PDE) addition (based on own research). 
of extrusion-cooked starch in pellet form. The main goal of this technology is the production of organic packaging loose fillers. Lacourse and Altieri $(1989 ; 1991)$ patented the extrusion methods of hydroxypropylated amylase to replace common foamed polystyrene. The obtained materials have a better elasticity than products produced from native starch. Due to the linear nature of the structure, amylose is considered to be a better starch component in the production of foamed materials. Confirmation of this may be found in the number of studies reported in the literature (Bae and Lim, 1998; Chanvrier et al., 2007; Chinnaswamy and Bhattacharya, 1984; Finkenstadt et al., 2016).

The idea of using mixtures of polymers with biopolymers is the ability to obtain a decomposing product without losing valuable mechanical functional properties (Ashby, 2006; Kahvand and Fasihi, 2020; Kennedy and Knill, 1995; Mitrus and Mościcki, 2014). By adding hydrophobic polymers the resulting products have better water resistance and they are also more cost effective. Due to their physical and mechanical properties, special commercial value have microporous foamed materials have a special commercial value (pores in micrometres) (Asadi et al., 2021; Hao and Chang-yu, 2008). PE-LD together with starch is used in their production. Cunningham et al. (1991) found that the addition of no more than 10\% starch in polyurethane compositions did not adversely affect the thermal and mechanical properties of the foams. Similar results were reported by Mariam et al. (2008), who calculated that the thermal conductivity of starch based foams was $0.064 \mathrm{~W} \mathrm{~m}^{-1} \mathrm{~K}^{-1}$, which is comparable to 0.02 $0.04 \mathrm{~W} \mathrm{~m}^{-1} \mathrm{~K}^{-1}$ and $0.043-0.077 \mathrm{~W} \mathrm{~m}^{-1} \mathrm{~K}^{-1}$ as reported for polyurethane and polyethylene foams, respectively.

Microporous foamed materials can also be obtained using aerosols (Baudron et al., 2019). They can be obtained from materials that contain alumina, tungsten, iron, tin oxide, cellulose, albumin and gelatin. It should be noted, however, that the process of producing a biocomposed polymer is far more difficult than the production of its classical petrochemical counterpart. In this process, the favourable functioning of pores and the appropriate level of humidity is important as water plays an important role in the plasticizer and affects the expansion of the foamed material.

It is said that PLA plays an important role in biodegradable bioplastics production. It can also be used to make starch-based foamed materials (Cui et al., 2017; Fang and Hanna, 2000; Guan et al., 2005). The starch-PLA blend has good functional properties, but it is a hydrophilic material. In the process of producing starch-PLA foams, water and talc are often used as a foaming agent, which additionally acts as an effective nucleating agent. Wood meal can also be added to the material made from foamed PLA. With the increased amount of water absorbed, the properties of the foamed material deteriorate. According to Guan et al. (2005) one way to improve this negative feature is to use modified starches, such as acetylated starch. Unfortunately that increases the cost of production, and also exacerbates its mechanical properties. The lowest hardness value $(59.3 \pm 19.5 \mathrm{~N})$ was obtained for foams made from acetylated potato starch. With the increase in the amylose content of the tested starches, the hardness of the foamed extrudates increased (maximum value was $392.7 \pm 48.3 \mathrm{~N}$ ).

The use of natural fillers such as cellulose fibres, wood meal or oat hasps helps to lower the price and improve the poorer mechanical properties of the modified starch (Kupryaniuk et al., 2020; Masli et al., 2018). Yudanto and Pudjihastuti (2020) indicated that bio-based foams with low filler (cellulose) addition had an increased tensile strength (the maximum value was $4.548 \mathrm{MPa}$ ). When the optimal point of addition was obtained, the agglomeration of filler reduced the tensile strength of the products (minimum value was less than $1 \mathrm{MPa}$ ). A typical tensile strength for commercial foams (commercial name Styrofoam) is $0.1 \mathrm{MPa}$. So the obtained starch based foams with cellulose addition has a greater tensile strength and can meet commercial tensile strength standards.

The end of the 20th century was an intense period of research into the possibility of producing environmentally friendly foamed packaging materials (Sivertsen, 2007). Neumann and Seib (1993) have patented the technology for the production of biodegradable starch-based foamed materials in which polyvinyl alcohol is the functional additive. The product was made from a mixture of high-amylose corn starch (95\%) and polyvinyl alcohol (5\%). It has also been found that materials of this type may be an alternative to styrofoam. The first foamed polyvinyl alcohol added materials were patented by Lacourse and Altieri in 1989 and 1991 (Lui and Peng, 2005). Hutchinson et al. (1987) conducted their endurance tests on the basis of which they found the relationship between the mechanical properties and the bulk density of the foamed materials produced from corn starch. In Chinnaswamy and Hanna (1988), we can read about the optimum extrusion temperature of corn starch $\left(160^{\circ} \mathrm{C}\right)$ used to obtain the maximum degree of product expansion. It was also found in studies that the bulk density of the foams decreased with the increasing amylose content of the starch. Warburton et al. (1990) showed that, with lower starch content, cell wall thickness, density, Young's modulus, and the breaking strength of foamed materials increased. Wang et al. (1995) have demonstrated the dependence of the radial expansion factor and the specific density of the foamed material on the starch type.

Maize-based foams exhibited higher expansion ratios and a higher specific density than wheat extrudates. The work of Bhatnagar and Hanna (1995a), who discussed the effect of functional additives on the physical, mechanical and thermal properties of starch foams, proved useful for further research. Corn starch with a $25 \%$ amylose content, polystyrene and polymethyl methacrylate (PMMA) were used in the study. The filling agents were bicarbonates, urea 
and siloxanes. The foamed materials obtained were characterized by a high density $\left(30-59 \mathrm{~kg} \mathrm{~m}^{-3}\right)$ as compared to PS $\left(8.9 \mathrm{~kg} \mathrm{~m}^{-3}\right)$ commercial foams. In recent years, it has become popular to create "green polyethylene", which is also used for the production of environmentally friendly bottles and foams (Arif et al., 2007). The marketed product Green Cell ${ }^{\circledR}(\mathrm{GCF})$ is made from a mixture of corn starch and functional substances. Green foam is able to compete with synthetic materials due to its favourable damping properties and thermal resistance.

\section{CONCLUSIONS}

From the examples above we may observe that researchers are focused on enhancing our ability to produce new innovative bio-based products with optimal physical and functional qualities. Much work has been done to improve the mechanical and physical properties of foamed starch materials, in particular density, expansion factor, compressive strength and elasticity (Chong et al., 2021; Jalalian et al., 2019; Machado et al, 2020b). Even so, researchers were aware of the inferior quality of natural foams as compared to their synthetic counterparts (Fig. 7). However, it has proven to be possible to produce foams that are completely biodegradable under composting conditions and they are an attractive product that have the potential to be a cost effective replacement for plastic containers. In particular, this technology can be applied to products such as food containers, cups, pots, cutlery, etc. On the other hand, starch-based bioplastics show a significant degree of moisture sensitivity in both dry and humid climates and which limits their competitiveness in terms of cost production. These are the main factors limiting the commercialization of environmentally friendly foamed packaging materials. It is widely known that all new technical and technological developments in the
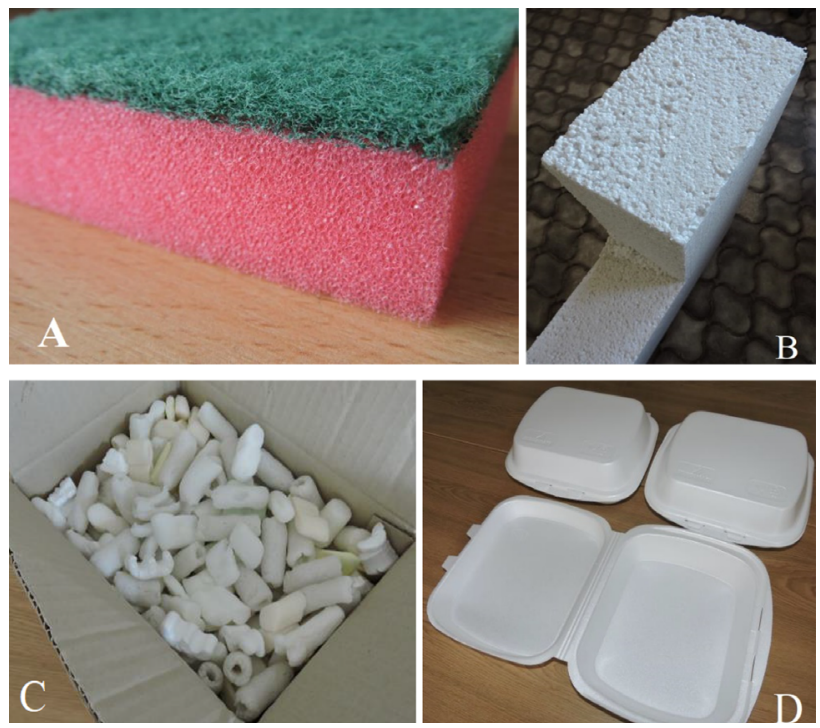

Fig. 7. Different types of foamed materials: A - polymer cleaning sponge, $\mathrm{B}$ - construction polystyrene, $\mathrm{C}$ - loose packaging fillers, $\mathrm{D}$ - food container (based on own research). packaging sector require social acceptance and the understanding of consumers concerning the possible negative consequences connected with their use. The level of awareness depends on the flow of information and the education of people. However, the whole point of the deliberations concerning environmental protection is often reduced to questions about cost effectiveness, in the case of bioplastics production, it is relatively easy to convince people to use them due to an increasing awareness among consumers of the benefits of their use. At present, the appropriate marketing activities can be used to improve consumer choices.

Conflict of interest: The Authors do not declare any conflict of interest.

\section{REFERENCES}

Abe M.M., Branciforti M.C., Nallin Montagnolli R., Marin Morales M.A., Jacobus A.P., and Brienzo M., 2022. Production and assessment of the biodegradation and ecotoxicity of xylan- and starch-based bioplastics. Chemosphere, 287, 132290, https://doi.org/10.1016/j.chemosphere.2021.132290

Abinader G., Lacoste C., Baillif M.L., Erre D., and Copinet A., 2015. Effect of the formulation of starch-based foam cushions on the morphology and mechanical properties. J. Cell. Plast., 51(1), 31-44, https://doi.org/10.1177/0021955X14527979

Altskar A., Andersson R., Boldizar A., Koch K., Stading M., Rigdahl M., and Thunwall M., 2008. Some effects of processing on the molecular structure and morphology of thermoplastic starch. Carbohydr. Polym., 71(4), 591-597, https://doi.org/10.1016/j.carbpol.2007.07.003

Andersen P.J., Kumar A., and Hodson S.K., 1999. Inorganically filled starch based fiber reinforced composite foam materials for food packaging. Mater. Res. Innov., 3(1), 2-8, https://doi.org/10.1007/s100190050118

Andrady A.L. (Ed.), 2003. Plastics and the environment. WileyInterscience: Hoboken, N.J, https://doi.org/10.1002/0471721557

Arif S., Burgess G., Narayan R., and Harte B., 2007. Evaluation of a biodegradable foam for protective packaging applications. Packag. Technol. Sci., 20(6), 413-419, https://doi.org/10.1002/pts.770

Asadi J., Korojy B., Hosseini S.A., and Alishahi M., 2021. Effect of cell structure on mechanical and bio-corrosion behavior of biodegradable $\mathrm{Mg}-\mathrm{Zn}-\mathrm{Ca}$ foam. Mater. Today Commun., 28, 102715, https://doi.org/10.1016/j.mtcomm.2021.102715

Ashby M.F., 2006. The properties of foams and lattices. Phil. Trans. R. Soc. A., 364(1838), 15-30, https://doi.org/10.1098/rsta.2005.1678

Atala A. and Mooney D.J. (Eds), 1997. Synthetic biodegradable polymer scaffolds. Tissue engineering. Birkhäuser: Boston, https://doi.org/10.1007/978-1-4612-4154-6

Atiwesh G., Mikhael A., Parrish C.C., Banoub J., and Le T.A.T., 2021. Environmental impact of bioplastic use: A review. Heliyon, 7(9), e07918, https://doi.org/10.1016/j.heliyon.2021.e07918 
Averous L., Moro L., Dole P., and Fringant C., 2000. Properties of thermoplastic blends: starch-polycaprolactone. Polymer, 41(11), 4157-4167, https://doi.org/10.1016/S0032-3861(99)00636-9

Averous L. and Boquillon N., 2004. Biocomposites based on plasticized starch: Thermal and mechanical behaviours. Carbohydr. Polym., 56(2), 111-122, https://doi.org/10.1016/j.carbpol.2003.11.015

Bae S.O. and Lim S.-T., 1998. Physical properties of extruded strands of hydroxypropylated normal and high-amylose corn starch. Cereal Chem. J., 75(4), 449-454, https://doi.org/10.1094/CCHEM.1998.75.4.449

Banhart J. and Baumeister J., 1998. Production methods for metallic foams. MRS Proc., 521, 121, https://doi.org/10.1557/PROC-521-121

Barmouz M. and Behravesh A.H., 2017. Statistical and experimental investigation on low density microcellular foaming of PLA-TPU/cellulose nano-fiber bio-nanocomposites. Polymer Testing, 61, 300-313, https://doi.org/10.1016/j.polymertesting.2017.05.032

Bastioli C. and Rapra Technology Limited (Eds), 2005. Handbook of biodegradable polymers. Rapra Technology: Shrewsbury.

Baudron V., Gurikov P., Smirnova I., and Whitehouse S., 2019. Porous starch materials via supercritical- and freezedrying. Gels, 5(1), 12, https://doi.org/10.3390/gels5010012

Bergel B.F., Araujo L.L., and Santana R.M.C., 2021. Effects of the addition of cotton fibers and cotton microfibers on the structure and mechanical properties of starch foams made from potato starch. Carbohydr. Polym. Technol. App., 2, 100167, https://doi.org/10.1016/j.carpta.2021.100167

Bergel B.F., Dias Osorio S., da Luz L.M., and Santana R.M.C., 2018. Effects of hydrophobized starches on thermoplastic starch foams made from potato starch. Carbohydr. Polym., 200, 106-114, https://doi.org/10.1016/j.carbpol.2018.07.047

Bergel B.F., Leite Araujo L., dos Santos da Silva A.L., and Campomanes Santana R.M., 2020. Effects of silylated starch structure on hydrophobization and mechanical properties of thermoplastic starch foams made from potato starch. Carbohydr. Polym., 241, 116274, https://doi.org/10.1016/j.carbpol.2020.116274

Bhatnagar S. and Hanna M., 1996. Starch-based plastic foams from various starch sources. Cereal Chem., 73(5), 601-604.

Bhatnagar S. and Hanna M.A., 1995a. Physical, mechanical, and thermal properties of starch-based plastic foams. Trans. ASAE, 38(2), 567-571, https://doi.org/10.13031/2013.27867

Bhatnagar S. and Hanna M.A., 1995b. Properties of extruded starch-based plastic foam. Ind. Crops. Prod., 4(2), 71-77, https://doi.org/10.1016/0926-6690(95)00016-6

Bonin M., 2010. An investigation into the properties of starchbased foams. School of Engineering \& Design Brunel University, U.K.

Borchardt J.K., 2004. Porous structures for tissue engineering. Mater. Today, 7(12), 26, https://doi.org/10.1016/S1369-7021(04)00562-0

Brodin M., Vallejos M., Opedal M.T., Area M.C., and ChingaCarrasco G., 2017. Lignocellulosics as sustainable resources for production of bioplastics - A review. J. Clean. Prod., 162, 646-664, https://doi.org/10.1016/j.jclepro.2017.05.209
Bruscato C., Malvessi E., Brandalise R.N., and Camassola M., 2019. High performance of macrofungi in the production of mycelium-based biofoams using sawdust - Sustainable technology for waste reduction. J. Clean. Prod., 234, 225-232, https://doi.org/10.1016/j.jclepro.2019.06.150

Cha J.Y., Chung D.S., and Seib P.A., 1999. Effects of extrusion temperature and moisture content on mechanical properties of starch-based foams. Trans. ASAE, 42(6), 1765-1770, https://doi.org/10.13031/2013.13339

Cha J.Y., Chung D.S., Seib P.A., Flores R.A., and Hanna M.A., 2001. Physical properties of starch-based foams as affected by extrusion temperature and moisture content. Ind. Crops. Prod., 14(1), 23-30, https://doi.org/10.1016/S0926-6690(00)00085-6

Chaireh S., Ngasatool P., and Kaewtatip K., 2020. Novel composite foam made from starch and water hyacinth with beeswax coating for food packaging applications. Int. J. Biol. Macromol., 165, 1382-1391, https://doi.org/10.1016/j.ijbiomac.2020.10.007

Chanvrier H., Appelqvist I.A.M., Bird A.R., Gilbert E., Htoon A., Li Z., Lillford P.J., Lopez-Rubio A., Morell M.K., and Topping D.L., 2007. Processing of novel elevated amylose wheats: Functional properties and starch digestibility of extruded products. J. Agric. Food Chem., 55(25), 10248-10257, https://doi.org/10.1021/jf0718650

Chaudhary A.L., Torley P., Halley P., McCaffery N., and Chaudhary D., 2009. Amylose content and chemical modificationeffectsonthermoplasticstarchfrommaize-Processing and characterisation using conventional polymer equipment. Carbohydr. Polym., 78, 917-925, https://doi.org/10.1016/j.carbpol.2009.07.023

Chauvet M., Sauceau M., Baillon F., and Fages J., 2021. Blending and foaming thermoplastic starch with poly (lactic acid) by $\mathrm{CO}_{2}$-aided hot melt extrusion. J. Appl. Polym. Sci., 138(14), 50150, https://doi.org/10.1002/app.50150

Chen J., Wang Y., Liu J., and Xu X., 2020. Preparation, characterization, physicochemical property and potential application of porous starch: A review. Int. J. Biol. Macromol., 148, 1169-1181, https://doi.org/10.1016/j.ijbiomac.2020.02.055

Chen Y., Zhang Z.Y., Ishikawa Y., and Maekawa T., 2002. Mechanical properties and water resistance of an acetylated starch-based plastic. Trans. ASAE, 45(4), 1051, https://doi.org/10.13031/2013.9919

Chinnaswamy R. and Bhattacharya K.R., 1984. Relationship between amylose content and expansion characteristics of parboiled rice. J. Cereal Sci., 2(4), 273-279, https://doi.org/10.1016/S0733-5210(84)80015-6

Chinnaswamy R. and Hanna M. A., 1988. Relationship between amylose content and extrusion-expansion properties of cornstarches. Cereal Chem., 65, 138-143.

Chocyk D., Gladyszewska B., Ciupak A., Oniszczuk T., Mościcki L., and Rejak A., 2015. Influence of water addition on mechanical properties of thermoplastic starch foils. Int. Agrophys, 29(3), 267-273, https://doi.org/10.1515/intag-2015-0031 
Chong J.W.R., Khoo K.S., Yew G.Y., Leong W.H., Lim J.W., Lam M.K., Ho Y.-C., Ng H.S., Munawaroh H.S.H., and Show P.L., 2021. Advances in production of bioplastics by microalgae using food waste hydrolysate and wastewater: A review. Biores. Technol., 342, 125947, https://doi.org/10.1016/j.biortech.2021.125947

Cinelli P., Chiellini E., Lawton J.W., and Imam S.H., 2006. Foamed articles based on potato starch, corn fibers and poly(vinyl alcohol). Polym. Degrad. Stab., 91(5), 1147-1155, https://doi.org/10.1016/j.polymdegradstab.2005.07.001

Cruz-Tirado J.P., Tapia-Blácido D.R., and Siche R., 2017. Influence of proportion and size of sugarcane bagasse fiber on the properties of sweet potato starch foams. IOP Conf. Ser.: Mater. Sci. Eng. 225012180 , https://doi.org/10.1088/1757-899X/225/1/012180

Cucina M., de Nisi P., Tambone F., and Adani F., 2021. The role of waste management in reducing bioplastics' leakage into the environment: A review. Bioresour. Technol., 337, 125459, https://doi.org/10.1016/j.biortech.2021.125459

Cui C.-H., Yan D.-X., Pang H., Jia L.-C., Xu X., Yang S., Xu J.-Z., and Li Z.-M., 2017. A high heat-resistance bioplastic foam with efficient electromagnetic interference shielding. Chem. Eng. J., 323, 29-36, https://doi.org/10.1016/j.cej.2017.04.050

Cunningham R.L., Carr M.E., and Bagley E.B., 1991. Polyurethane foams extended with corn flour. Cereal Chem., 68, 258-261.

De Graaf R.A. and Janssen L.P.B.M., 2000. The production of a new partially biodegradable starch plastic by reactive extrusion. Polym. Eng. Sci., 40(9), 2086-2094, https://doi.org/10.1002/pen.11340

Doi Y. and Fukuda K., 1994. Biodegradable plastics and polymers: Proc. 3rd Int. Scientific Workshop On Biodegradable Plastics And Polymers, Osaka, Japan, November 9-11, 1993. Elsevier Science.

Engel J.B., Ambrosi A., and Tessaro I.C., 2019. Development of biodegradable starch-based foams incorporated with grape stalks for food packaging. Carbohydr. Polym., 225, 115234, https://doi.org/10.1016/j.carbpol.2019.115234

Engel J.B., Luchese C.L., and Tessaro I.C., 2021. How are the properties of biocomposite foams influenced by the substitution of cassava starch for its residual sources? Food Hydrocoll., 118, 106790, https://doi.org/10.1016/j.foodhyd.2021.106790

European Bioplastics, 2021a. Frequently asked questions on bioplastics,

https://www.european-bioplastics.org/news/publications

European Bioplastics, 2021b. Summary bioplastic market update 2020 , https://www.european-bioplastics.org/news/publications

Fang Q. and Hanna M.A., 2000. Functional properties of polylactic acid starch-based loose-fill packaging foams. Cereal Chem. J., 77(6), 779-783, https://doi.org/10.1094/CCHEM.2000.77.6.779

Filli K., Sjöqvist M., Öhgren C., Stading M., and Rigdahl M., 2011. Development and characterization of extruded biodegradable foams based on zein and pearl millet flour. Annu. trans. Nord. Rheol. Soc., 19, 1-7.
Finkenstadt V.L., Felker F.C., Fanta G.F., Kenar J.A., Selling G.W., Hornback K.J., and Fisk D.L., 2016. Extruded foams prepared from high amylose starch with sodium stearate to form amylose inclusion complexes. J. Appl. Polym. Sci., 133, 43251, https://doi.org/10.1002/app.43251

Follain N., Joly C., Dole P., Roge B., and Mathlouthi M., 2006. Quaternary starch based blends: Influence of a fourth component addition to the starch/water/glycerol system. Carbohydr. Polym, 63(3), 400-407, https://doi.org/10.1016/j.carbpol.2005.09.008

Gamarano D. de S., Pereira I.M., da Silva M.C., Mottin A.C., and Ayres E., 2020. Crystal structure transformations in extruded starch plasticized with glycerol and urea. Polym. Bull., 77(9), 4971-4992, https://doi.org/10.1007/s00289-019-02999-2

Ganjyal G.M., Weber R., and Hanna M.A., 2007. Laboratory composting of extruded starch acetate and poly lactic acid blended foams. Bioresour. Technol., 98(16), 3176-3179, https://doi.org/10.1016/j.biortech.2006.10.030

Gáspár M., Benkő Zs., Dogossy G., Réczey K., and Czigány T., 2005. Reducing water absorption in compostable starchbased plastics. Polym. Degrad. Stab., 90(3), 563-569, https://doi.org/10.1016/j.polymdegradstab.2005.03.012

Gendron R. (Ed.), 2004. Thermoplastic foam processing: Principles and development. CRC Press, https://doi.org/10.1201/9780203502167

Georges A., Lacoste C., and Damien E., 2018. Effect of formulation and process on the extrudability of starch-based foam cushions. Ind. Crops. Prod., 115, 306-314, https://doi.org/10.1016/j.indcrop.2018.02.001

Geramipour T. and Oveisi H., 2017. Effects of foaming parameters on microstructure and compressive properties of aluminum foams produced by powder metallurgy method. Trans. Nonferrous Met. Soc. China, 27(7), 1569-1579, https://doi.org/10.1016/S1003-6326(17)60178-X

Gibson L.J. and Ashby M.F., 2001. Cellular solids: structure and properties. Cambridge solid state science series. Cambridge Univ. Press: Cambridge.

Glenn G. and Irving D., 2005. Starch-based microcellular foams. Cereal Chem., 72(2), 155-161.

Glenn G.M. and Orts W.J., 2001. Properties of starch-based foam formed by compression/explosion processing. Ind. Crops. Prod., 13(2), 135-143, https://doi.org/10.1016/S0926-6690(00)00060-1

Guan J., Eskridge K.M., and Hanna M.A., 2005. Acetylated starch-polylactic acid loose-fill packaging materials. Ind. Crops. Prod., 22(2), 109-123, https://doi.org/10.1016/j.indcrop.2004.06.004

Guan J., Fang Q., and Hanna M.A., 2004. Selected functional properties of extruded starch acetate and natural fibers foams. Cereal Chem. J., 81(2), 199-206, https://doi.org/10.1094/CCHEM.2004.81.2.199

Guan J. and Hanna M.A., 2004. Functional properties of extruded foam composites of starch acetate and corn cob fiber. Ind. Crops. Prod., 19(3), 255-269, https://doi.org/10.1016/j.indcrop.2003.10.007

Guan J. and Hanna M.A., 2005. Selected morphological and functional properties of extruded acetylated starch-polylactic acid foams. Ind. Eng. Chem. Res., 44(9), 3106-3115, https://doi.org/10.1021/ie049786q 
Gurusamy Thangavelu S.A., Mukherjee M., Layana K., Dinesh Kumar C., Sulthana Y.R., Rohith Kumar R., Ananthan A., Muthulakshmi V., and Mandal A.B., 2020. Biodegradable polyurethanes foam and foam fullerenes nanocomposite strips by one-shot moulding: Physicochemical and mechanical properties. Mater. Sci. Semicond. Process., 112, 105018, https://doi.org/10.1016/j.mssp.2020.105018

Guy R.C.E. (Ed.), 2001. Extrusion cooking: technologies and applications. Woodhead publishing in food science and technology. CRC Press; Woodhead: Boca Raton, Cambridge.

Hao L. and Chang-yu H., 2008. Research progress in structureproperties relationships of closed cell polymer foams. Chinese Polym. Bull.

Hidalgo-Crespo J., Jervis F.X., Moreira C.M., Soto M., and Amaya J.L., 2020. Introduction of the circular economy to expanded polystyrene household waste: A case study from an Ecuadorian plastic manufacturer. Procedia CIRP, 90, 49-54, https://doi.org/10.1016/j.procir.2020.01.089

Ho B.T., Roberts T.K., and Lucas S., 2018. An overview on biodegradation of polystyrene and modified polystyrene: the microbial approach. Crit. Rev. Biotechnol., 38(2), 308-320, https://doi.org/10.1080/07388551.2017.1355293

Hutchinson R.J., Siodlak G.D.E., and Smith A.C., 1987. Influence of processing variables on the mechanical properties of extruded maize. J. Mater Sci., 22(11), 3956-3962, https://doi.org/10.1007/BF01133345

Jalalian M., Jiang Q., Coulon A., Storb M., Woodward R., and Bismarck A., 2019. Mechanically whipped phenolic froths as versatile templates for manufacturing phenolic and carbon foams. Mater. Des., 168, 107658, https://doi.org/10.1016/j.matdes.2019.107658

Jiang T., Duan Q., Zhu J., Liu H., and Yu L., 2020. Starch-based biodegradable materials: Challenges and opportunities. Adv. Industr. Engin. Polymer Res., 3(1), 8-18, https://doi.org/10.1016/j.aiepr.2019.11.003

Jin F.-L., Zhao M., Park M., and Park S.-J., 2019. Recent trends of foaming in polymer processing: a Review. Polymers, 11(6), 953, https://doi.org/10.3390/polym11060953

Kahvand F. and Fasihi M., 2020. Microstructure and physical properties of thermoplastic corn starch foams as influenced by polyvinyl alcohol and plasticizer contents. Int. J. Biol. Macromol., 157, 359-367, https://doi.org/10.1016/j.ijbiomac.2020.04.222

Kaisangsri N., Kerdchoechuen O., and Laohakunjit N., 2012. Biodegradable foam tray from cassava starch blended with natural fiber and chitosan. Ind. Crops. Prod., 37(1), 542546, https://doi.org/10.1016/j.indcrop.2011.07.034

Kaisangsri N., Kerdchoechuen O., and Laohakunjit N., 2014. Characterization of cassava starch based foam blended with plant proteins, kraft fiber, and palm oil. Carbohydr. Polym, 110, 70-77, https://doi.org/10.1016/j.carbpol.2014.03.067

Kaisangsri N., Kowalski R.J., Kerdchoechuen O., Laohakunjit N., and Ganjyal G.M., 2019. Cellulose fiber enhances the physical characteristics of extruded biodegradable cassava starch foams. Ind. Crops. Prod., 142, 111810, https://doi.org/10.1016/j.indcrop.2019.111810

Kaza S., Yao L.C., Bhada-Tata P., and Van Woerden F., 2018. What a waste 2.0: A global snapshot of solid waste management to 2050, https://doi.org/10.1596/978-1-4648-1329-0
Kennedy J.F. and Knill C.J., 1995. Biodegradable plastics and polymers. (Studies in Polymer Science, 12), (Eds Y. Doi and K. Fukuda). Elsevier Science, Amsterdam, 1994. Polym. Int., 36(3), 299-299,

https://doi.org/10.1002/pi.1995.210360311

Konovalenko Ig.S., Toktohoev Ch.O., Konovalenko Iv.S., Smolin A.Yu., and Psakhie S.G., 2014. Study of the mechanical properties of ceramic composites with different volume of plastic filler. Procedia Materials Science, 3, 942947, https://doi.org/10.1016/j.mspro.2014.06.153

Kupryaniuk K., Oniszczuk T., Combrzyński M., Czekała W., and Matwijczuk A., 2020. The influence of corn straw extrusion pretreatment parameters on methane fermentation performance. Materials, 13(13), 3003, https://doi.org/10.3390/ma13133003

Lacourse N.L. and Altieri P., 1989. Biodegradable packaging material and the method of preparation thereof. US Patent 4863655.

Lacourse N.L. and Altieri P., 1991. Biodegradable shaped products and the method of preparation thereof. US Patent 5043196.

Lawton J.W., Shogren R.L., and Tiefenbacher K.F., 2004. Aspen fiber addition improves the mechanical properties of baked cornstarch foams. Ind. Crops. Prod., 19(1), 41-48, https://doi.org/10.1016/S0926-6690(03)00079-7

Lee S.-T. and Scholz D.P.K. (Eds), 2009. Polymeric foams: technology and developments in regulation, process, and products. Polymeric foams. CRC Press: Boca Raton, https://doi.org/10.1201/9781420061260

Lee S.Y., Eskridge K.M., Koh W.Y., and Hanna M.A., 2009. Evaluation of ingredient effects on extruded starch-based foams using a supersaturated split-plot design. Ind. Crops. Prod., 29(2-3), 427-436, https://doi.org/10.1016/j.indcrop.2008.08.003

Lehmhus D., Busse M., Herrmann A.S., and Kayvantash K. (Eds), 2013. Structural materials and processes in transportation. First edition ed. Wiley-VCH: Weinheim, Germany, https://doi.org/10.1002/9783527649846

Li H., Mahmood N., Ma Z., Zhu M., Wang J., Zheng J., Yuan Z., Wei Q., and Xu C. (Chunbao), 2017. Preparation and characterization of bio-polyol and bio-based flexible polyurethane foams from fast pyrolysis of wheat straw. Ind. Crops. Prod., 103, 64-72, https://doi.org/10.1016/j.indcrop.2017.03.042

Li P., Zhu X., Kong M., Lv Y., Huang Y., Yang Q., and Li G., 2021. Fully biodegradable polylactide foams with ultrahigh expansion ratio and heat resistance for green packaging. Int. J. Biol. Macromol., 183, 222-234, https://doi.org/10.1016/j.ijbiomac.2021.04.146

Liu P., Chen G.-F., and Liu P., 2014. Porous materials: processing and applications. BH, Butterworh-Heinemann/Elsevier: Amsterdam.

Liu P.S., 2010. Mechanical relation for porous metal foams under complex loads of triaxial tension and compression. Mater. Des., 31(4), 2264-2269, https://doi.org/10.1016/j.matdes.2009.10.007

Lui W.-B. and Peng J., 2005. Physical, mechanical, biodegradable properties and energy absorption behavior of corn grit-polyvinyl alcohol cushioning extrudates. J. Food Engin., 71(1), 73-84, https://doi.org/10.1016/j.jfoodeng.2004.10.021 
Machado C.M., Benelli P., and Tessaro I.C., 2020a. Effect of acetylated starch on the development of peanut skin-cassava starch foams. Int. J. Biol. Macromol., 165, 1706-1716, https://doi.org/10.1016/j.ijbiomac.2020.10.048

Machado C.M., Benelli P., and Tessaro I.C., 2020b. Study of interactions between cassava starch and peanut skin on biodegradable foams. Int. J. Biol. Macromol., 147, 1343-1353, https://doi.org/10.1016/j.ijbiomac.2019.10.098

Marcovich N.E., Kurańska M., Prociak A., Malewska E., and Kulpa K., 2017. Open cell semi-rigid polyurethane foams synthesized using palm oil-based bio-polyol. Ind. Crops. Prod., 102, 88-96, https://doi.org/10.1016/j.indcrop.2017.03.025

Mariam I., Cho K.Y., and Rizvi S.S.H., 2008. Thermal properties of starch-based biodegradable foams produced using supercritical fluid extrusion (SCFX). Int. J. Food Propert., 11(2), 415-426, https://doi.org/10.1080/10942910701444705

Masli M.D.P., Gu B., Rasco B.A., and Ganjyal G.M., 2018. Fiber-rich food processing byproducts enhance the expansion of cornstarch extrudates. J. Food Sci., 83(10), 2500-2510, https://doi.org/10.1111/1750-3841.14290

Miladinov V.D. and Hanna M.A., 2001. Temperatures and ethanol effects on the properties of extruded modified starch. Ind. Crops. Prod., 13(1), 21-28, https://doi.org/10.1016/S0926-6690(00)00048-0

Mitrus M., 2006. Microstructure of thermoplastic starch polymers. Int. Agrophys., 20(1), 31-35.

Mitrus M., Combrzyński M., Kupryaniuk K., Wójtowicz A., Oniszczuk T., Kręcisz M., Matysiak A., Smurzyńska A., and Mościcki L., 2016. A study of the solubility of biodegradable foams of thermoplastic starch. J. Ecol. Eng., 17(4), 184-189, https://doi.org/10.12911/22998993/64554

Mitrus M. and Mościcki L., 2014. Extrusion-cooking of starch protective loose-fill foams. Chem. Engin. Res. Design, 92(4), 778-783, https://doi.org/10.1016/j.cherd.2013.10.027

Mittal V. (Ed.), 2013. Polymer nanocomposite foams. CRC Press, Taylor \& Francis Group, LLC, Boca Raton, USA.

Nabar Y. and Narayan R., 2006. Analysis of the dynamic behavior of a starch foam extrusion process. J. Appl. Polym. Sci., 101(6), 3983-3995, https://doi.org/10.1002/app.22942

Nabar Y., Narayan R., and Schindler M., 2006a. Twin-screw extrusion production and characterization of starch foam products for use in cushioning and insulation applications. Polym. Eng. Sci., 46(4), 438-451, https://doi.org/10.1002/pen.20292

Nabar Y.U., Draybuck D., and Narayan R., 2006b. Physicomechanical and hydrophobic properties of starch foams extruded with different biodegradable polymers. J. Appl. Polym. Sci., 102(1), 58-68, https://doi.org/10.1002/app.22127

National Institute of Industrial Research (India), 2006. Complete book on biodegradable plastics and polymers: recent development, properties, analysis, materials \& processes. Asia Pacific Business: Delhi, India.

Niaounakis M., 2015. Biopolymers: processing and products. PDL Handbook Series. Elsevier/WA, William Andrew is an imprint of Elsevier: Amsterdam ; Boston.

Neumann P.E. and Seib P.A., 1993. Starch-based biodegradable packaging filler and method of preparing same. US Patent 5165383
Oniszczuk T., WójtowiczA., Mościcki L., Mitrus M., Kupryaniuk K., Kusz A., and Bartnik G., 2016. Effect of natural fibres on the mechanical properties of thermoplastic starch. Int. Agrophys., 30(2), 211-218,

https://doi.org/10.1515/intag-2015-0080

Oniszczuk T., Wójtowicz A., Oniszczuk A., Mitrus M., Combrzyński M., Kręcisz M., and Mościcki L., 2015. Effect of processing conditions on selected properties of starch-based biopolymers. Agriculture and Agricultural Science Procedia, 7, 192-197,

https://doi.org/10.1016/j.aaspro.2015.12.016

Pachori S., Sarkar A., Dutta A., Palanivelu J., and Chidambaram R., 2019. Synthesis methods of starch-based polymer foams and its comparison with conventional polymer foams for food packaging applications. In: Polymers for agri-food applications (Ed. T.J. Gutiérrez). Springer International Publishing: Cham, 317-338, https://doi.org/10.1007/978-3-030-19416-1 16

Park S.K. and Hettiarachchy N.S., 1999. Physical and mechanical properties of soy protein-based plastic foams. J. Am. Oil Chem. Soc., 76(10), 1201-1205, https://doi.org/10.1007/s11746-999-0094-3

Parra D.F., Carr L.G., Ponce P., Tadini C.C., and Lugão A.B., 2006. Biodegradable foams made of cassava starch and fibers: influence in the mechanical properties. In: International Symposium on Future of Food Engineering. CIGR.

Phromsopha T. and Baimark Y., 2021. Study on phase compatibility and water resistance of thermoplastic starch foams coated with flexible poly(L-lactide)-b-polyethylene glycolb-poly(L-lactide) bioplastics. Mater. Today Commun., 26, 101844, https://doi.org/10.1016/j.mtcomm.2020.101844

Prapruddivongs C. and Wongpreedee T., 2020. Use of eggshell powder as a potential hydrolytic retardant for citric acidfilled thermoplastic starch. Powder Technol., 370, 259-267, https://doi.org/10.1016/j.powtec.2020.05.076

Pushpadass H.A., Babu G.S., Weber R.W., and Hanna M.A., 2008. Extrusion of starch-based loose-fill packaging foams: effects of temperature, moisture and talc on physical properties. Packag. Technol. Sci., 21(3), 171-183, https://doi.org/10.1002/pts.809

Rajak D.K. and Gupta M., 2020. Introduction to metallic foams. In: An insight into metal based foams, advanced structured materials. Springer Singapore: Singapore, 1-20, https://doi.org/10.1007/978-981-15-9069-6 1

Razza F., Degli Innocenti F., Dobon A., Aliaga C., Sanchez C., and Hortal M., 2015. Environmental profile of a bio-based and biodegradable foamed packaging prototype in comparison with the current benchmark. J. Clean. Prod., 102, 493-500, https://doi.org/10.1016/j.jclepro.2015.04.033

Rosato D.V., Rosato D.V., and Rosato M.V., 2004. Plastic product material and process selection handbook. Elsevier: Kidlington, Oxford, UK ; New York, USA, https://doi.org/10.1016/B978-185617431-2/50005-0

Salgado P.R., Schmidt V.C., Molina Ortiz S.E., Mauri A.N., and Laurindo J.B., 2008. Biodegradable foams based on cassava starch, sunflower proteins and cellulose fibers obtained by a baking process. J. Food Engin., 85(3), 435-443, https://doi.org/10.1016/j.jfoodeng.2007.08.005

Sivertsen K., 2007. Polymer foams. Polymer physics, Spring, Massachusetts Institute of Technology, USA. 
Shey J., Imam S.H., Glenn G.M., and Orts W.J., 2006. Properties of baked starch foam with natural rubber latex. Ind. Crops. Prod., 24(1), 34-40, https://doi.org/10.1016/j.indcrop.2005.12.001

Shogren R.L., Lawton J.W., and Tiefenbacher K.F., 2002. Baked starch foams: starch modifications and additives improve process parameters, structure and properties. Ind. Crops. Prod., 16(1), 69-79, https://doi.org/10.1016/S0926-6690(02)00010-9

Song W., Barber K., and Lee K.-Y., 2017. Heat-induced bubble expansion as a route to increase the porosity of foam-templated bio-based macroporous polymers. Polymer, 118, 97-106, https://doi.org/10.1016/j.polymer.2017.04.058

Soykeabkaew N., Supaphol P., and Rujiravanit R., 2004. Preparation and characterization of jute- and flax-reinforced starch-based composite foams. Carbohydr. Polym, 58(1), 53-63, https://doi.org/10.1016/j.carbpol.2004.06.037

Srisuwan Y. and Baimark Y., 2021. Improvement of water resistance of thermoplastic starch foams by dip-coating with biodegradable polylactide-b-polyethylene glycol-bpolylactide copolymer and its blend with poly(D-lactide). Prog. Org. Coat, 151, 106074, https://doi.org/10.1016/j.porgcoat.2020.106074

Steinbüchel A. (Ed.), 2005. Biopolymers Online: Biology • Chemistry $\bullet$ Biotechnology $\bullet$ Applications. $1^{\text {st }}$ ed. Wiley, https://doi.org/10.1002/3527600035

Stevens E.S., 2002. Why do composters care? How green are green plastics? Biocycle, 43, 42-45, https://doi.org/10.1515/9780691214177

Su B.-L., 2012. Hierarchically structured porous materials: from nanoscience to catalysis, separation, optics, energy, and life science. Wiley-VCH: Weinheim, https://doi.org/10.1002/9783527639588

Szpilyk M., Lubczak R., and Lubczak J., 2021. The biodegradable cellulose-derived polyol and polyurethane foam. Polymer Testing, 100, 107250, https://doi.org/10.1016/j.polymertesting.2021.107250

Tatarka P. and Cunningham R., 1998. Properties of protective loose-fill foams. J. Appl. Polymer Sci., 67, 1157-1176, https://doi.org/10.1002/(SICI)1097-4628(19980214)67:7<1157 ::AID-APP1>3.0.CO;2-F

Todd C.S. and Kuznetsova V., 2011. Closed-cell foam skin thickness measurement using a scanning electron microscope. Microsc. Microanal., 17(5), 772-778, https://doi.org/10.1017/S1431927611000420

Van Tuil R., Van Heemst J., and Schennink G., 2001. Potato starch based resilient thermoplastic foams. In: Biorelated polymers (Eds E. Chiellini, H. Gil, G. Braunegg, J. Buchert, P. Gatenholm and M. van der Zee). Springer US: Boston, MA, 3-17, https://doi.org/10.1007/978-1-4757-3374-7 1

Wang L., Ganjyal G.M., Jones D.D., Weller C.L., and Hanna M.A., 2005. Modeling of bubble growth dynamics and nonisothermal expansion in starch-based foams during extrusion. Adv. Polym. Technol., 24(1), 29-45, https://doi.org/10.1002/adv.20030
Wang L., Lee R.E., Wang G., Chu R.K.M., Zhao J., and Park C.B., 2017. Use of stereocomplex crystallites for fullybiobased microcellular low-density poly(lactic acid) foams for green packaging. Chem. Engin. J., 327, 1151-1162,

https://doi.org/10.1016/j.cej.2017.07.024

Wang X., Huang L., Zhang C., Deng Y., Xie P., Liu L., and Cheng J., 2020. Research advances in chemical modifications of starch for hydrophobicity and its applications: A review. Carbohydr. Polym, 240, 116292, https://doi.org/10.1016/j.carbpol.2020.116292

Wang W., Flores R.A., and Huang C., 1995. Physical Properties of Two Biological Cushioning Materials from Wheat and Corn Starches. Cereal Chem., 72(1), 38-41.

Warburton S.C., Donald A.M., and Smith A.C., 1990. The deformation of brittle starch foams. J. Mater Sci., 25(9), 4001-4007, https://doi.org/10.1007/BF00582472

Willett J.L. and Shogren R.L., 2002. Processing and properties of extruded starch/polymer foams. Polymer, 43(22), 59355947, https://doi.org/10.1016/S0032-3861(02)00497-4

Wu G., Xie P., Yang H., Dang K., Xu Y., Sain M., Turng L.-S., and Yang W., 2021. A review of thermoplastic polymer foams for functional applications. J. Mater. Sci., 56(20), 11579-11604, https://doi.org/10.1007/s10853-021-06034-6

Xu Y.X., Dzenis Y., and Hanna M.A., 2005. Water solubility, thermal characteristics and biodegradability of extruded starch acetate foams. Ind. Crops. Prod., 21(3), 361-368, https://doi.org/10.1016/j.indcrop.2004.05.004

Yang Z., Graiver D., and Narayan R., 2013. Extrusion of humidity-resistant starch foam sheets. Polym. Eng. Sci., 53(4), 857-867, https://doi.org/10.1002/pen.23326

Yu L., Dean K., and Li L., 2006. Polymer blends and composites from renewable resources. Prog. Polym. Sci., 31(6), 576-602, https://doi.org/10.1016/j.progpolymsci.2006.03.002

Yudanto Y.A. and Pudjihastuti I., 2020. Characterization of physical and mechanical properties of biodegradable foam from maize flour and paper waste for sustainable packaging material. Int. J. Eng. Appl. Sci. Technol., 5(8), 1-8, https://doi.org/10.33564/IJEAST.2020.v05i08.001

Zhang J.-F. and Sun X., 2007a. Biodegradable foams of poly(lactic acid)/starch. I. Extrusion condition and cellular size distribution. J. Appl. Polym. Sci., 106(2), 857-862, https://doi.org/10.1002/app.26715

Zhang J.-F. and Sun X., 2007b. Biodegradable foams of poly(lactic acid)/starch. II. Cellular structure and water resistance: Biodegradable Foams of PLA/Starch. J. Appl. Polym. Sci., 106(5), 3058-3062, https://doi.org/10.1002/app.26697

Zhang X., Teng Z., and Huang R., 2020. Biodegradable starch/ chitosan foam via microwave assisted preparation: morphology and performance properties. Polymers, 12(11), 2612, https://doi.org/10.3390/polym12112612

Zhou J., Song J., and Parker R., 2006. Structure and properties of starch-based foams prepared by microwave heating from extruded pellets. Carbohydr. Polym, 63(4), 466-475, https://doi.org/10.1016/j.carbpol.2005.09.019 